Article

\title{
Long-Term Forest Paired Catchment Studies: What Do They Tell Us That Landscape-Level Monitoring Does Not?
}

\author{
Daniel G. Neary \\ USDA Forest Service, Rocky Mountain Research Station, 2500 South Pine Knoll Drive, Flagstaff, AZ 86001, USA; \\ dneary@fs.fed.us; Tel.: +1-928-853-1861; Fax: +1-928-556-2130 \\ Academic Editors: Ge Sun and James M. Vose \\ Received: 15 December 2015; Accepted: 22 July 2016; Published: 29 July 2016

\begin{abstract}
Forested catchments throughout the world are known for producing high quality water for human use. In the 20th Century, experimental forest catchment studies played a key role in studying the processes contributing to high water quality. The hydrologic processes investigated on these paired catchments have provided the science base for examining water quality responses to natural disturbances such as wildfire, insect outbreaks, and extreme hydrologic events, and human-induced disturbances such as timber harvesting, site preparation, prescribed fires, fertilizer applications, pesticide usage, rainfall acidification, and mining. This paper compares and contrasts the paired catchment approach with landscape-level water resource monitoring to highlight the information on hydrologic processes provided by the paired catchment approach that is not provided by the broad-brush landscape monitoring.
\end{abstract}

Keywords: forest catchments; long-term studies; monitoring; water quantity; water quality

\section{Introduction}

The most sustainable and best quality freshwater sources in the world originate in forested watersheds [1-5]. The biological, chemical, and physical characteristics of forest soils are particularly well suited to delivering high quality water to streams (e.g., low in sediment content and nutrient load, and contain low amounts of bacteria and other microorganisms). They are also excellent in moderating the climatic extremes that affect stream hydrology and water quality [6]. Forest soils are usually characterized by high porosities, low bulk density, and high saturated hydraulic conductivities and infiltration rates [7]. Consequently, surface runoff is rare in forest environments, and most rainfall moves to streams by subsurface flow pathways where nutrient uptake, cycling, and contaminant sorption processes are rapid. Because of the dominance of subsurface flow processes, peak flows are moderated and baseflows with high water quality are prolonged $[8,9]$.

In many parts of the world, municipalities ultimately rely on forested watersheds to provide adequate quantities of high quality water for continually growing demand [1]. This is particularly true in semi-arid regions where water supplies are limited, water quality is affected by high mineral content, and human populations are large or growing rapidly. Forest soils provide the perfect conditions for creating high quality water supplies [6]. Research using paired catchments provides the scientific basis for understanding disturbance effects in forests and led to development of Best Management Practices (BMPs) for sustaining water quality [10].

The early 20th century was unique in that it had the beginnings of paired catchment research in several parts of the world. The Sperbelgraben and Rappengraben experimental catchments were established in 1903 near Emmental, Switzerland [11]. This was followed by establishment of the Ota watershed study in Japan in 1908 and the Wagon Wheel Gap study in Colorado, USA, in 1910 [12,13]. 
Paired catchment experiments have been reviewed by a number of authors [14-22]. Most of these reviews have dealt with the topic of water yield. However, many of the paired catchment experiments initially designed for water yield research have been expanded to include water quality.

Landscape-level hydrologic monitoring is being carried out by a number of agencies throughout the world. These include the U.S. Geological Survey (USGS) in the United States, the National Institute of Water and Atmospheric Research in New Zealand, CSIRO and the Bureau of Meteorology in Australia, Environment Canada in Canada, municipal and state water authorities in Germany, Federal Service for Hydrometeorology and Environmental Monitoring in Russia, and the State Environmental Protection Agency and the Ministry of Water Resources in China, to mention a few.

This paper provides a historical perspective of the many accomplishments of water quantity and quality research over the past century, made possible by using the paired catchment methodology. It examines the paired catchment approach versus landscape level monitoring to describe what each approach provides in terms of hydrological science and what type of information is needed for watershed management in the 21st Century.

\section{U.S. Geological Survey Landscape-Level Monitoring}

\subsection{Background}

The U.S. Geological Survey (USGS) has been gathering hydrologic and climatic data for more than 100 years at some of its monitoring stations. Long-term streamflow data generated at more than 7200 sites create environmental baseline data sets that can be used to assess important parameters and significant changes [23]. For example, gathering long-term water data helps answer questions like:

- What is the height of stream rise in 100-year floods?

- How effective are stream restoration and streamside management practices?

- What are current stream levels in respect to historic highs and lows?

- What are the trends in streamflows with respect to current climate and variations?

- What are the characteristics of streamflows in different biogeographical provinces?

Disadvantages of landscape level time-trend monitoring include hydrograph time resolution, sampling frequency for chemical analysis, climate variability, stream gauge accuracy, and a mixture of land uses. This approach provides a "snapshot" of hydrological conditions but is way too coarse for teasing out hydrological processes and their causes. Climate variability between sites is a major problem particularly when convective thunderstorms are a main source of rainfall input. Some USGS gauges have proper weirs but others do not and utilize natural control sections. This is understandable for large catchments with a wide range of flows. However, this method does not produce records that are as accurate as those derived from standard weirs. The mixture of land uses and conditions common with the landscape-level gauges makes it difficult to sort out causes and effects attributable to specific uses and conditions. Chemical analyses may be limited and spaced out over different time frames, making it difficult to make inter-basin comparisons. Metadata availability is often limited by different gauge histories compared to paired catchments.

As indicated above, streamflow records can provide an important history of climatic variation over a hydrologic basin [24]. This ability is a function of the collection of water data in the absence of confounding factors such as land use change and management impacts that override climate signals. National streamflow records that are relatively free of confounding anthropogenic influences are important for studying and understanding of the variation in surface-water conditions throughout the United States. Confounding effects are difficult to avoid, especially if large basins are used for study. The smaller catchments used for paired catchment research are usually better at avoiding these effects but the method is not "foolproof" [1,3].

Providing users with the history of climatic and hydrologic variation over a catchment is a primary objective of the national hydrologic records generated by the landscape-level USGS streamflow 
recording system [24]. The USGS National Water Storage and Retrieval System (WATSTORE) gauging station data are reviewed jointly with hydrology and climate data specialists in each USGS District office. The resulting assemblage of stations, each with its respective period of record, is called the Hydro-Climatic Data Network, or HCDN. The HCDN is composed of 1,659 sites throughout the country and its territories. This produces a network of 73,231 water years of daily mean discharge values for evaluating water resource conditions across the many diverse landscapes of the United States. For each station in the HCDN, the appropriate daily mean discharge values are compiled by month and year, and statistical characteristics, including monthly mean discharges and annual mean, minimum and maximum discharges, are tabulated. The stream discharge data are assessed and compared in a companion report on national water resources. This process provides an understanding of the variation in national surface-water conditions but does not evaluate the impacts of anthropogenic disturbances such as agriculture, forestry, urbanization, vegetation conversion, and wildfires.

Currently, the USGS collects streamflow and other data on variable time intervals that range from 15 min to yearly at more than 7200 sites that are gauging stations for streamflow. Most of the stations are funded and operated in cooperation with other federal agencies, such as the U.S. Army Corps of Engineers, the U.S. Forest Service, the Bureau of Land Management, the Bureau of Reclamation, and the U.S. Fish and Wildlife Service, and with state, Tribal, county, and municipal agencies. These cooperators use the USGS-derived data for making decisions such as when to withdraw water from rivers or reservoirs for agricultural and municipal use, and whether or not to permit discharge of treated wastewater into surface waters. Provisional data from most of the gauging sites are available on-line in within hours of recording (http:/ / waterdata.usgs.gov/nwis). The USGS water resources system provides access to its and cooperator water-resources data collected at approximately 1.5 million sites in all 50 States, the District of Columbia, Puerto Rico, the Virgin Islands, Guam, American Samoa and the Commonwealth of the Northern Mariana Islands. These sites include estuaries, lakes, streams, springs, wells, caves, wetlands, and industrial and municipal facilities.

\subsection{Monitoring Scales and Settings}

USGS water resource monitoring aims to investigate local problems and trends in a specific stream, county, state, or large catchment systems such as the Columbia River or the Mississippi River Basin. Uniform methods of sampling and analysis are selected to provide consistent information across and within landscapes. Monitoring is conducted at sites that are representative of national watersheds so that comprehensive comparisons and assessments can be made at larger scales. This multi-scale approach helps with determining if certain types of water yield or water quality issues are isolated, biogeographical region dependent, or wide-spread nationally. This approach allows streams, rivers, and lakes to be compared to those in other geographic and environmental settings. Therefore, the data can help answer comparative questions including the following:

- Is the water quality of a particular stream typical of streams in the Atlantic Coastal Plain?

- Are streams in the arid west experiencing reduced flows and elevated salinity?

- Are cation and anion concentrations exceeding water quality standards?

- Are stream baseflows diminishing, stabilizing, or increasing across specific hydrologic regions or nationally?

\subsection{A Monitoring Protocol}

Landscape-level monitoring is necessary to ensure that water resources can continue to support the many different ways water resources are used [25]. This level of large scale monitoring is also used to determine the effectiveness of protection and restoration measures. The information obtained from monitoring helps with state and national prioritizing of water quantity and quality the issues to be addressed by state and Federal programs, and for selecting the geographic areas in which to focus water research and restoration efforts. This approach helps to ensure cost-effective water resource management. 
Effective landscape-level monitoring has the attributes of being is regular, long-term, and inclusive of biological, physical, and chemical parameters. It should be "regular" to detect changes in water resource conditions. In many instances, changes are more important in determining water quantity and quality problems. Regular monitoring at consistent time intervals allows identification of changes in the noisy background of water parameter fluctuations. Allied to "regular", is the monitoring characteristic of "long-term". Collection of water resource data in the "long-term", using consistent and comparable methodology, is necessary for identification of trends or patterns that indicate there are significant changes in water resource parameters. Water quality is constantly changing on a diurnal, seasonal, and annual basis. To separate real trends from short-term changes, consistent and systematic data are required over the long term. However, without the comparative data generated by a "paired watershed" approach, it might be difficult to determine "cause and effect" from observed water resource changes or the potential magnitude of those changes. Even then the effort might be intractable and detailed study and focused monitoring may be required to solve problems.

Water quantity (streamflow) is an important companion parameter to water quality in that the quantity of streamflow is a critical in determining water quality and interpreting water-quality trends. The potential effects of contaminant concentrations and loadings on drinking-water supplies and aquatic habitats depend largely on the amount of water flowing in streams. Higher flows usually mean that rivers and streams have the capacity to carry a greater load of chemical contaminants and sediment. High flows result in increased bedload scour and suspended sediment transport, in part because of greater overland runoff relative to baseflows. On the other hand, greater streamflows may result in a reduction of concentrations and an apparent improvement in water quality. This could include concentrations of nonpoint source pollutants, loading of pollutants, biological content, and thermal conditions. All are components of water quality but the former is usually measured the most.

Access to streamflow data at the appropriate temporal resolution allows for more accurate evaluation of water-quality data. An observed trend in water quality (for example, increasing concentrations of a chemical contaminant over a six-month period) may indicate an actual water-quality change or may be the indirect result of differences in flow volumes when the water samples were collected. Long intervals (monthly, yearly, and biennial) between water sampling aggravates the problem of separating management-related water quality changes from volume-seasonal effects.

The USGS collects samples from streams across the United States and its territories, and analyzes these samples for chemical, physical, and biological properties [25]. Data are collected for studies that range from national in scale, such as the National Water-Quality Assessment Program (NAWQA), to studies in small watersheds.

Through its landscape level monitoring program, the USGS has no regulatory responsibilities, but the agency focuses on evaluating the entire national water resource. Important uses that motivate USGS landscape-level monitoring include drinking water sources, water used for irrigation, livestock water supply, industrial water supplies, and recreation. The USGS water resources data thereby complement the data collected by the States and by EPA, which focus on monitoring for compliance with regulations, and land management agencies, such as the U.S. Forest Service, that are concerned about management activity impacts.

\section{Paired Catchment Studies}

\subsection{Rationale and Criticism}

As mentioned in the Introduction, paired catchment studies began in the early 20th Century and expanded considerably from the 1930s through the 1970s [15]. The rationale for the use of this methodology in hydrologic studies was providing solid data for predicting the effects of forest cover on water yield. Hibbert [14] reviewed 39 paired catchment studies across the world and came to the conclusion that these studies supported several generalizations:

1. Reduction of forest cover increases water yield. 
2. Establishment of forests on sparsely vegetated land in low rainfall areas reduces water yield.

3. Responses to vegetation management are highly variable due to climate regime, vegetation type, geology, soils, area treated, and aspect.

Many more paired catchment studies since 1967 reinforced Hibbert's conclusions [14]. Indeed, at that time and still today, much of the knowledge about forest vegetation effects on the hydrologic cycle and man's influences came from paired catchment studies.

At about the same time a number of criticisms arose about the use of paired catchment studies in hydrological science. The main criticisms were that paired catchment experiments were too costly, unrepresentative, used leaky watersheds, had questionable application of results, and did not contribute to scientific progress on hydrological processes [26,27]. A rebuttal by Hewlett [28] titled In Defense of Experimental Watersheds clearly pointed out that the long-term time-trend studies proposed as an alternative to paired catchment research were weaker because there are usually no climate controls (calibration period). These studies also lacked a control catchment needed to separate vegetation cover effects from climate effects. Hewlett and his co-authors [28] believed strongly that time-trend studies are circumstantial and that paired catchment studies are strong evidence of forest vegetation effects on the water cycle. Hence, they concluded that the paired catchment methodology was scientifically sound and had a secure future in hydrological science.

\subsection{Disturbance Effects}

Most forest catchment water quality studies reported in the literature deal with tree harvesting and post-harvest site preparation since much of the early interest in paired catchment science related to vegetation management to increase water yield. In addition, harvesting practices were considered to produce the most disruptions to ecological processes and therefore the most influence on water quality. Other disturbances include wildfire, prescribed fire, pesticide application, recreation activities, wildland-urban development, sewage discharges, landslides, grazing, mining, and invasive species spread.

Since forest fertilization has been a basic feature of intensive forest management throughout the world, the impact of fertilizers on water quality has been an issue easily addressed by paired catchment research [29]. Paired catchments provided a sound basis for acid deposition research in the 1980s and 1990s [30], and continue to support scientific endeavors on climate change in the 21st century [31].

A number of water parameters are affected by disturbances, but only streamflow and nutrients will be discussed in the limited space available for this paper. Other papers present a much more detailed discussion of these topics $[9,16,20,32,33]$.

\subsection{Water Yield}

Most paired catchment studies were established to determine the impact of forest management on water yield (Tables 1 and 2). These studies have allowed the comparison of forest harvesting in a number of forest ecosystems and across a range of precipitation regimes and evapotranspiration gradients. Measured first year increases in streamflow volumes have ranged from none (with $457 \mathrm{~mm}$ annual precipitation [34]) to $280 \%$ (with $1,020 \mathrm{~mm}$ annual precipitation [35]). In absolute amounts, the range is from $0 \mathrm{~mm}$ [34] to $650 \mathrm{~mm}$ [36]. Paired watershed studies allow this comparison of undisturbed and disturbed because of the nature and designs of the studies. These watershed studies also facilitate the comparisons and evaluations of the effects of forest types on water yield (conifer vs. deciduous). In general, there is a significant increase in streamflow with 100\% forest cutting.

Increases in annual streamflow volumes in area-depths in forested catchments caused by vegetation removal or manipulation begin at around $500 \mathrm{~mm}$ annual precipitation and increase as precipitation input increases (Figure 1, Table 1). These data were developed from paired watershed studies in a range of forest ecosystems in North America, Europe, Asia, Africa, Australia, and New Zealand (Tables 1 and 2). Most are from the USA due to substantial investments by government agencies such as the U.S. Forest Service. 
Table 1. First year streamflow responses to forest harvesting by precipitation amount, 450 to $1200 \mathrm{~mm}$ precipitation, forest ecosystems in Europe, North America, Australia, and Japan. Adapted from [20].

\begin{tabular}{cccccccc}
\hline Forest type & Location & Ppt. & $\begin{array}{c}\text { Mean Annual } \\
\text { Flow }\end{array}$ & Cut & $\begin{array}{c}\text { 1st Year } \\
\text { Inc. }\end{array}$ & $\begin{array}{c}\text { Percent } \\
\text { Increase }\end{array}$ & Reference \\
\hline & & $\mathbf{m m}$ & $\mathbf{m m}$ & $\mathbf{\%}$ & $\mathbf{m m}$ & $\mathbf{\%}$ & \\
\hline Pinyon-juniper & Arizona USA & 457 & 20 & 100 & 0 & 0 & {$[34]$} \\
Spruce-fir & Alberta Canada & 513 & 147 & 100 & 84 & 57 & {$[37]$} \\
Aspen-conifer & Colorado USA & 536 & 157 & 100 & 34 & 22 & {$[38]$} \\
Eucalyptus spp. & Victoria Australia & 596 & 86 & 100 & 20 & 23 & {$[39]$} \\
Ponderosa pine & Arizona USA & 570 & 153 & 100 & 96 & 63 & {$[40]$} \\
Oak woodland & California USA & 635 & 144 & 99 & 33 & 23 & {$[41]$} \\
Pine-spruce & Sweden & 732 & 271 & 100 & 371 & 119 & {$[42]$} \\
Spruce-fir-pine & Colorado USA & 770 & 340 & 40 & 84 & 25 & {$[43]$} \\
Aspen-birch & Minnesota USA & 775 & 107 & 100 & 45 & 42 & {$[44]$} \\
Spruce-fir & Alberta Canada & 840 & 310 & 100 & 79 & 25 & {$[45]$} \\
Slash pine & Florida USA & 1020 & 48 & 74 & 134 & 280 & {$[35]$} \\
Hardwood & Japan & 1153 & 293 & 100 & 209 & 18 & {$[46]$} \\
\hline
\end{tabular}

Table 2. First year streamflow responses to forest harvesting by precipitation amount, 1200 to $2600 \mathrm{~mm}$ precipitation forest ecosystems in North America, Africa, Australia, and New Zealand. Adapted from [20].

\begin{tabular}{cccccccc}
\hline Forest type & Location & Ppt. & $\begin{array}{c}\text { Mean Annual } \\
\text { Flow }\end{array}$ & Cut & $\begin{array}{c}\text { 1st Year } \\
\text { Inc. }\end{array}$ & $\begin{array}{c}\text { Percent } \\
\text { Increase }\end{array}$ & Reference \\
\hline & & $\mathbf{m m}$ & $\mathbf{m m}$ & $\mathbf{\%}$ & $\mathbf{m m}$ & $\mathbf{\%}$ & \\
\hline Coastal redwoods & California & 1200 & 67 & 100 & 34 & 51 & {$[47]$} \\
Mixed Hardwoods & Georgia USA & 1219 & 467 & 100 & 254 & 54 & {$[48]$} \\
Northern hardwoods & New Hampshire & 1230 & 710 & 100 & 343 & 48 & {$[49]$} \\
Loblolly pine & Arkansas & 1317 & 214 & 100 & 101 & 47 & {$[50]$} \\
Dry Eucalpytus & Victoria Australia & 1520 & 330 & 95 & 350 & 106 & {$[51]$} \\
Mixed hardwoods & North Carolina & 1900 & 880 & 100 & 362 & 41 & {$[52]$} \\
Montane forest & Kenya Africa & 2014 & 568 & 100 & 457 & 80 & {$[53]$} \\
Cascade Douglas-fir & Oregon USA & 2388 & 1376 & 100 & 462 & 34 & {$[54]$} \\
Coastal Douglas-fir & Oregon USA & 2483 & 1885 & 82 & 370 & 20 & {$[55,56]$} \\
Beech and podocarps & New Zealand & 2600 & 1500 & 100 & 650 & 43 & {$[36]$} \\
\hline
\end{tabular}

The largest and most consistent increases in streamflow with vegetation removal occur between 2000 and $2750 \mathrm{~mm}$ (Figure 1, Table 2). Although landscape-level gauging has been conducted in virtually every region and country around the world, the best data in terms of quality and length of record come from forest paired watershed studies [15]. Projects that incorporated controlled, human interventions such as logging have been able to develop the best understanding of hydrologic processes [17]. Landscape-level monitoring that minimized or avoided disturbances would not have achieved the same of understanding [21].

A considerable amount of research has been conducted in the past on the hydrologic effects of forest disturbances, primarily harvesting, on over 105+ individual paired catchments. The results have been summarized in a number of syntheses $[15-17,20,57,58]$. These studies have been very expensive to install, maintain, and monitor. Their existence is a tribute to the substantial dedication to their continuity by hydrologic scientists. The earliest catchment experiments were installed in Switzerland, Japan, and the United States in the first ten years of the twentieth century when the continuity of water supplies was a big issue. Some have been in existence since the 1930s. Scientists and watershed managers have studied harvesting intensities, configurations, and timing with a view to optimizing water yield and quality. With a $100 \%$ clearcut harvest, first-year water yield increases reported in the literature generally range from $0 \%$ to $280 \%$ over a range of forest vegetation from juniper (dry) to tropical (wet) (Table 1). The absolute amount of water yield is strongly related to a number of factors 
at the time of harvesting such as the annual rainfall, vegetation type, ET regime, aspect and slope, leaf area reduction, geology, soil type, soil moisture, and soil depth $[6,17,59]$. Although the water yields increase the first year after harvesting and increase with total precipitation, the percentage increase is poorly correlated to precipitation amount (Figure 1). Although tropical forests have higher rainfall, increases after harvesting are reduced by high year-round ET. Indeed, the greatest variation occurs at $100 \%$ harvest because other factors in the hydrologic equation override transpiration reduction. Vegetation type is strongly correlated to streamflow increases after forest harvesting [60]. Broadleaved forests have the highest mean increase in water quantity after harvesting $(237 \mathrm{~mm})$ compared to coniferous forests $(161 \mathrm{~mm})$ or mixed conifer-broadleaved forests $(170 \mathrm{~mm})$ [58].

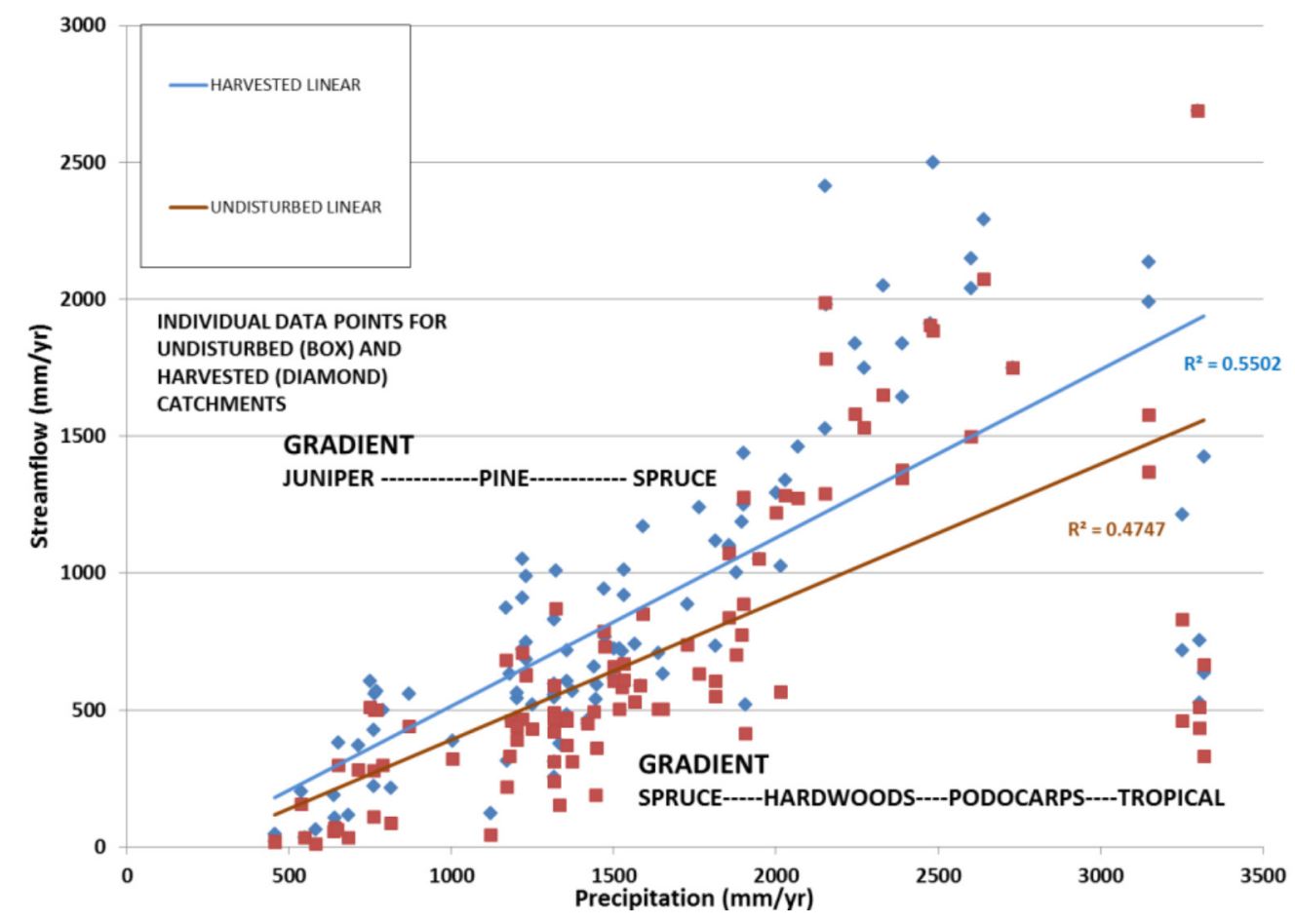

Figure 1. Streamflow increases produced by harvesting paired catchment studies. Adapted from $[15-17,20,57,58]$.

Harvesting of forests has been used to augment municipal water supplies because of the resulting increases in water yield [15]. The duration of the response depends on a number of factors. Generally, the increase in total water yield after harvesting is considered to be a benefit, and not of sufficient magnitude to produce adverse hydrologic or ecosystem effects (e.g., flooding). However, vigorously growing young forest stands provide and opposite response. They can cause subsequent water yield declines after initial increases due to rapid resprouting. Short-rotation Eucalyptus spp. plantations in Australia and South Africa are good examples [61,62]. E. regnans and E. delegatensis are the main culprits but not all Eucalyptus species produce the same effect.

\subsection{Water Quality}

Although the initial focus of early catchment research was water yield, the adoption of the paired catchment approach set the stage for examining physical, chemical, and biological processes that controlled nutrient cycling and other water quality related functions of forest catchments [63]. The untreated half of catchment study pairs provides the opportunity to study natural processes that controlled water quality. However, the disturbances to these processes produced by practices such as harvesting, site preparation, road construction, fire, fertilization, herbicide use and insect outbreaks provide the real insight into natural catchment processes that affect water quality. 
Nutrients such as nitrate nitrogen $\left(\mathrm{NO}_{3}-\mathrm{N}\right)$ in streamflow from forested watersheds have been an issue for 50 years or more because of the release of $\mathrm{NO}_{3}-\mathrm{N}$ after harvesting or other disturbances and the low water quality standard. Water quality is a justified concern of watershed management since many municipalities depend on high quality water coming from forested and other non-urbanized lands for their water supplies.

However, there have been many misperceptions about the impacts of forest management practices on water quality. Paired catchments provide the ideal locations for examining the real management effects on the important water quality parameters such as $\mathrm{NO}_{3}-\mathrm{N}$. Of the 30 paired watershed studies listed in Tables 3 and 4 that examined $\mathrm{NO}_{3}-\mathrm{N}$ concentrations after partial or complete clearcutting, only one showed an alarming increase $\left(0.3\right.$ to $\left.11.9 \mathrm{mg} \cdot \mathrm{L}^{-1}\right)$ that exceeded the international water quality standard $\left(10 \mathrm{mg} \cdot \mathrm{L}^{-1}\right)$ [59].

Table 3. Paired catchment comparison of the effects of forest harvesting on mean $\mathrm{NO}_{3}-\mathrm{N}$ concentrations in streamflow in North America the year after cutting. Adapted from [20,57,64].

\begin{tabular}{|c|c|c|c|c|}
\hline \multirow[t]{2}{*}{ Forest Type } & \multirow[t]{2}{*}{ Location } & \multicolumn{2}{|c|}{$\mathrm{NO}_{3}-\mathrm{N}$} & \multirow[t]{2}{*}{ Reference } \\
\hline & & Uncut & Cut & \\
\hline & & \multicolumn{2}{|c|}{$\mathrm{mg} \cdot \mathrm{L}^{-1}$} & \\
\hline Lodgepole Pine & Alberta, Canada & 0.2 & 0.7 & {$[65]$} \\
\hline Spruce, Fir & British Columbia, Canada & 0.1 & 0.2 & {$[66]$} \\
\hline Spruce, Fir & British Columbia, Canada & $<0.1$ & 0.5 & {$[67]$} \\
\hline Northern Hardwoods & New Brunswick, Canada & 0.1 & 0.6 & [68] \\
\hline Spruce, Fir, Pine, Birch & Quebec. Canada & $<0.1$ & $<0.1$ & [69] \\
\hline Spruce, Fir, Pine & Nova Scotia, Canada & $<0.1$ & 0.3 & [70] \\
\hline Mixed Conifer & Montana, USA & 0.1 & 0.2 & {$[71]$} \\
\hline Spruce, Fir & Colorado, USA & $<0.1$ & $<0.1$ & [72] \\
\hline Mixed Conifer & Idaho, USA & 0.2 & 0.2 & [73] \\
\hline Douglas-fir & Oregon, USA & $<0.1$ & 0.2 & [74] \\
\hline Mixed Conifers & Oregon, USA & $<0.1$ & 0.2 & [74] \\
\hline Loblolly Pine & Georgia, USA & 0.1 & 0.1 & [48] \\
\hline Loblolly Pine & South Carolina, USA & $<0.1$ & $<0.1$ & [75] \\
\hline Mixed Hardwoods & North Carolina, USA & $<0.1$ & 0.1 & [76] \\
\hline Aspen, Birch, Spruce & Minnesota, USA & 0.1 & 0.2 & {$[44]$} \\
\hline Mixed Hardwoods & West Virginia, USA & 0.1 & 0.5 & [77] \\
\hline Northern Hardwoods & New Hampshire, USA & 0.3 & 11.9 & [59] \\
\hline
\end{tabular}

Table 4. Paired catchment comparison of the effects of forest harvesting on mean $\mathrm{NO}_{3}-\mathrm{N}$ concentrations in streamflow in Europe, Africa, Asia, and the South Pacific the year after cutting. Adapted from [20,64].

\begin{tabular}{ccccc}
\hline Forest Type & Location & \multicolumn{2}{c}{ NO $_{3}-\mathbf{N}$} & Reference \\
\hline & & Uncut & Cut \\
& & mg. $\mathbf{L}^{-1}$ & $\mathbf{~ m g} \cdot \mathbf{L}^{-\mathbf{1}}$ \\
\hline Native Beech-Podocarp & Chile & $<0.1$ & $<0.1$ & {$[78]$} \\
Spruce, Fir, Peat & Finland & $<0.1$ & 0.1 & {$[79]$} \\
Spruce, Fir, Beech & Germany & 0.7 & 1.0 & {$[80]$} \\
Native Hardwoods & Japan & 0.7 & 1.6 & {$[81]$} \\
Radiata Pine & New Zealand & $<0.1$ & 0.5 & {$[82]$} \\
Beech-Podocarp & New Zealand & $<0.1$ & $<0.1$ & {$[61]$} \\
Radiata Pine & New Zealand & $<0.1$ & 0.2 & {$[83]$} \\
Evergreen Forest/Scrub & South Africa & $<0.1$ & 0.1 & {$[61]$} \\
Pine, Spruce, Hardwood & Sweden & 0.1 & 0.2 & {$[84]$} \\
Spruce, Moor & United Kingdom & 0.2 & 0.3 & {$[85]$} \\
Eucalyptus spp. & Victoria, Australia & $<0.1$ & $<0.1$ & {$[86]$} \\
\hline & \# 4 years after cutting & &
\end{tabular}


Pierce et al. [59] raised concerns about water quality and forestry practices 45 years ago but was shown to be an anomaly [87]. All of the studies listed in Tables 3 and 4 post-dated the Pierce et al. [59] Hubbard Brook study and came to the same conclusion that there would be increases in $\mathrm{NO}_{3}-\mathrm{N}$ but they would be minor and not anywhere close to the $10 \mathrm{mg} \mathrm{L}^{-1}$ standard that the Hubbard Brook study violated. The side-by-side comparison of disturbed watersheds with undisturbed controls highlighted an analysis in 1977 that this case is an outlier in the literature and not the general ecosystem trend [87]. Hubbard Brook was unique in that vegetation regrowth was prevented by herbicides. Lacking plants to take up nitrogen liberated by harvesting an old-growth forest, $\mathrm{NO}_{3}-\mathrm{N}$ concentrations in streamflow soared. Paired watershed studies like those listed in Tables 3 and 4 have been able to improve understanding of nutrient cycling and the changes in water quality which occur after harvesting. Landscape-level monitoring may have picked up the rise in $\mathrm{NO}_{3}-\mathrm{N}$, but then been unable to clearly demonstrate the source of the extra nitrogen.

\section{Method Comparisons}

A comparison of the characteristics of landscape-level monitoring and paired catchment water studies is presented in Table 5. This highlights the question raised by the title of this paper, "Long-term forest paired catchment studies: What do they tell us that landscape-level monitoring does not?"

Table 5. Comparison of characteristics of landscape-level monitoring and paired watershed research.

\begin{tabular}{ccc}
\hline Watershed Characteristic & Landscape-Level Monitoring & Paired Watershed Approach \\
\hline Short-term Studies & Yes & Yes \\
Long-term Studies & Yes & Yes \\
Large Scale Basins & Yes & Usually Not \\
Small Scale Basins & Some & Yes \\
Research Primary Objective & No & Yes \\
Water Yield Studies & Yes, but Limited & Yes \\
Water Quality Studies & Yes, but Limited & Yes \\
Process Research Capable & Usually Not & Yes \\
Individual Watershed Expense & Moderate & Moderate to High \\
Program Operating Expense & High & Moderate to Low \\
National Assessment Capable & Yes & Limited \\
Program Commitment & National & Regional to Local \\
Trend Detection & Moderate & High to Very High \\
Focus on Disturbance Effects & No & Yes \\
Disturbance Assessment & Moderate & High to Very High \\
Disturbance Comparisons & No & Yes \\
Cooperators Used & Yes & Yes \\
Web-Available Information & Yes & Yes \\
\hline
\end{tabular}

In their Preface to the 2012 publication "Revisiting Experimental Catchment Studies in Forest Hydrology", the editors clearly point out that much of what is known about the hydrological role of forests has derived from paired catchment experiments [88]. Paired catchment studies are designed for research into hydrologic processes whereas landscape-level monitoring is not (Table 5). They also focus on management related disturbances (e.g., harvesting, site preparation, fertilization, herbicide application, road construction and use, prescribed fire etc.) while landscape-level monitoring seeks to gather hydrologic information in the absence of most anthropogenic disturbances. Paired catchment studies are able to do this efficiently, while landscape-level monitoring does not. Most paired catchment studies involve process research that is aimed at understanding the hydrologic and ecological processes that control water flow and nutrient cycling [89]. Because of their design as before-after-control-impact experiments (BACI), paired catchment studies are more accurate in elucidating the water yield and quality impacts of forest disturbances. Landscape-level monitoring is more focused on broad scale trends. However, paired catchment studies are better suited to detecting trends amidst the "noise" that 
is common with water studies. Disturbance comparisons can be made with paired catchments studies, but rarely so with landscape-level monitoring due to confounding factors with the latter methodology.

\section{Summary and Conclusions}

This paper compared two different approaches to collect information on water resources in the United States, although other countries have similar approaches. The USGS uses a landscape monitoring approach to acquire data on water resources from over 7200 gauging stations to report on the status and trends of water resources in the country. It also utilizes data from cooperators to assemble information on 1.5 million sites in the USA. The other approach is the paired catchment method. It involves the BACI method of comparing side-by-side catchments to determine the impact of various disturbances. A variety of research organizations utilize the paired catchment approach because of the type of information they are interested in. While the landscape-level monitoring is important for discerning national water resources trends, most of what is known about the hydrological role of forests comes from paired catchment studies using the BACI method.

The hydrologic and ecological impacts of specific land management practices and the functioning of the hydrologic cycle in forest ecosystems have been developed from studies using the paired catchment approach over the past century. Hewlett [28] clearly pointed out that the long-term time-trend studies proposed as an alternative to paired catchment research were weaker because there are no climate controls (calibration period). These studies also lack a control catchment needed to separate vegetation cover effects from climate effects. Hewlett and his co-authors stated strongly that time-trend studies are circumstantial, and that paired catchment studies are strong evidence of forest vegetation effects on the water cycle [28]. Hence, they concluded that the paired catchment methodology was scientifically sound and had a secure future in hydrological science.

Both methods need to be maintained in the light of climate changes going on in the beginning of the 21st Century, but paired catchment studies are absolutely essential and are more likely to identify changes in hydrologic processes. Some of the water relationships determined by research in the 20th Century could be altered by different dynamics in the atmosphere with climate change. The legacy of 20th century paired catchment studies provides a solid and more accurate framework for evaluating and predicting 21st century changes.

Both approaches must be carried forward into the 20th Century. Landscape-level monitoring covers a greater extent of the USA and other nations as well as their forests. It would be cost-prohibitive for all the USGS sites to function as paired catchments (doubling or tripling the funding commitment). Paired catchments provide the venue for detailed research on a limited number of forest types and an attraction for national programs such as the USA Long Term Ecological Research network and the National Ecological Observatory Network [89]. There will need to be solid commitments from scientific organizations, government agencies, and private organizations and enterprises to achieve this goal.

Acknowledgments: The author would like to acknowledge the USDA Forest Service Research and Development division for providing support and training during his 38-year career in order to develop insights and experience in conducting paired watershed science. He would also like to thank SCION Forest Research Institute, Rotorua, New Zealand, for getting him into this aspect of the hydrological sciences.

Conflicts of Interest: The author declares no conflict of interest.

\section{References}

1. Lee, R. Forest Hydrology; Columbia University Press: New York, NY, USA, 1980; p. 349.

2. Dissmeyer, G.E., Ed.; Drinking water from forests and grasslands: A synthesis of the scientific literature. In USDA Forest Service, General Technical Report SRS-39; Southern Research Station: Asheville, NC, USA, 2000; p. 246.

3. Brooks, K.N.; Ffolliott, P.F.; Gregersen, H.M.; DeBano, L.F. Hydrology and the Management of Watersheds; Iowa State Press: Ames, IA, USA, 2003; p. 574. 
4. Barten, P.K.; Ernst, C.E. Land conservation and watershed management for source protection. J. Am. Water Works Assoc. 2004, 96, 121-135.

5. Emelko, M.B.; Silins, U.; Bladon, K.D.; Stone, M. Implications of land disturbance on drinking water treatability in a changing climate: Demonstrating the need for "source water supply and protection" strategies. Water Res. 2011, 45, 461-472. [CrossRef] [PubMed]

6. Neary, D.G.; Ice, G.G.; Jackson, C.R. Linkages between forest soils and water quantity and quality. Forest Ecol. Manag. 2009, 258, 2269-2281. [CrossRef]

7. Neary, D.G. Impacts of wildfire severity on hydraulic conductivity in forest, woodland, and grassland soils. In Hydraulic Conductivity_Issues, Determination and Applications; Elango, L., Ed.; INTECH: Rijeka, Croatia, 2011; pp. 123-142.

8. Vertessy, R.A. The impacts of forestry on streamflows: A review. In Forest Management for the Protection of Water Quality and Quantity, Proceedings of the Second Erosion in Forests Meeting, Warburton, Australia, 4-6 May 1999; Croke, J., Lane, P., Eds.; Cooperative Research Centre for Catchment Hydrology: Canberra, Australia; pp. 93-109.

9. Ice, G.G.; Stednick, J.D. A Century of Forest and Wildland Watershed Lessons; Society of American Foresters: Bethesda, MD, USA, 2004; p. 287.

10. Ice, G. History of innovative Best Management Practice development and its role in addressing water quality limited waterbodies. J. Environ. Eng. 2004, 130, 684-689. [CrossRef]

11. Penman, H.L. Vegetation and Hydrology: Technical Communication No. 53, Commonwealth Bureau of Soils; Commonwealth Agricultural Bureau: Wallingford, UK, 1963.

12. Steen, H.K. The US Forest Service, a History; University of Washington Press: Seattle, WA, USA, 1976.

13. Neary, D.G. Changing perceptions of watershed management from a retrospective viewpoint. In Proceedings of Land Stewardship in the 21st Century: The Contributions of Watershed Management, Tucson, Arizona, USA, 13-16 March 2000; USDA Forest Service Proceedings RMRS-P-13, Rocky Mountain Research Station: Fort Collins, CO, USA, 2000; pp. 167-176.

14. Hibbert, A.R. Forest treatment effects on water yield. In International Symposium on Forest Hydrology; Sopper, W.W., Lull, H.W., Eds.; Pergamon Press: Oxford, UK, 1967; pp. 527-543.

15. Bosch, J.M.; Hewlett, J.D. A review of catchment experiments to determine the effect of vegetation changes on water yield and evapotranspiration. J. Hydrol. 1982, 55, 3-23. [CrossRef]

16. Binkley, D.; Brown, T.C. Forest practices as nonpoint sources of pollution in North America. Water Res. Bull. 1993, 29, 729-740. [CrossRef]

17. Neary, D.G.; Hornbeck, J.W. Impacts of harvesting practices on off-site environmental quality. In Impacts of Harvesting on Long-Term Site Productivity; Dyck, W.J., Cole, D.W., Comerford, N.B., Eds.; Chapman and Hall: London, UK, 1994; pp. 81-118.

18. Sahin, V.; Hall, M.J. The effects of afforestation and deforestation on water yields. J. Hydrol. 1996, 178, $293-309$. [CrossRef]

19. Stednick, J.D. Monitoring the effects of timber harvest on annual water yield. J. Hydrol. 1996, 176, 79-95. [CrossRef]

20. Neary, D.G. Environmental sustainability of forest energy production, 6.3 Hydrologic values. In Bioenergy from Sustainable Forestry: Guiding Principles and Practices; Richardson, J., Smith, T., Hakkila, P., Eds.; Elsevier: Amsterdam, The Netherlands, 2002; Chapter 6; pp. 36-67.

21. Andréassian, V. Water and forests: From historical controversy to scientific debate. J. Hydrol. 2004, $291,1-27$. [CrossRef]

22. Brown, A.E.; Zhang, L.; McMahon, T.A.; Western, A.W.; Vertessy, R.A. A review of paired catchment studies for determining changes in water yield resulting from alterations in vegetation. J. Hydrol. 2005, 310, $28-61$. [CrossRef]

23. Maupin, M.A.; Kenny, J.F.; Hutson, S.S.; Lovelace, J.K.; Barber, N.L.; Linsey, K.S. Estimated Use of Water in the United States in 2010; U.S. Geological Survey: Reston, VA, USA, 2014; p. 64.

24. Slack, J.R.; Landwehr, J. Hydro-climatic data network (HCDN); a U.S. Geological Survey streamflow data set for the United States for the study of climate variations, 1874-1988. U.S. Geological Survey Open-File Report 92-129; U.S. Geological Survey: Reston, VA, USA, 1992; p. 193. 
25. Horowitz, A.J.; Demas, C.R.; Fitzgerald, K.K.; Miller, T.L.; Rickert, D.A. U.S. Geological Survey protocol for the collection and processing of surface-water samples for the subsequent determination of inorganic constituents in filtered water. U.S. Geological Survey Open-File Report 94-539; U.S. Geological Survey: Reston, VA, USA, 1994; p. 57.

26. Ackermann, W.C. Guidelines for Research on the Hydrology of Small Watersheds; U.S. Department of the Interior, Office of Water Resources Research: Washington, DC, USA, 1966; p. 52.

27. Reynolds, E.C.R.; Layton, L. Research data for forest policy: The purpose, methods, and progress of forest hydrology. In Proceedings of the 9th British Commonwealth Forestry Conference, New Delhi, India; University of Oxford, Oxford, United Kingdom, 6-8 January 1968; pp. 1-16.

28. Hewlett, J.D.; Lull, H.W.; Reinhart, K.G. In defense of experimental watersheds. Water Resour. Res. 1969, 5, 306-316. [CrossRef]

29. Binkley, D.; Burnham, H.; Allen, H.L. Water quality impacts of forest fertilization. Forest Ecol. Manag. 1999, 121, 191-213. [CrossRef]

30. Likens, G.E.; Driscoll, C.T.; Buso, D.C. Long-term effects of acid rain: Response and recovery of a forest ecosystem. Science 1996, 272, 244-246. [CrossRef]

31. Bouraoui, F.; Grizzetti, B.; Granlund, K.; Rekolainen, S.; Bidoglio, G. Impact of climate change on the water cycle and nutrient losses in a Finnish catchment. Clim. Chang. 2004, 66, 109-126. [CrossRef]

32. Scatena, F.N. Goals of the report. In Drinking Water from Forests and Grasslands: A Synthesis of the Scientific Literature, 7-25. USDA Forest Service General Technical Report SRS-39; Dissmeyer, G.E., Ed.; Southern Research Station: Asheville, NC, USA, 2000; Chapter 2; p. 250.

33. Swanson, F.J.; Scatena, F.N.; Dissmeyer, G.E.; Fenn, M.E.; Verry, E.S.; Lynch, J.A. Watershed processes-Fluxes of water, dissolved constituents, and sediment. In Drinking Water from Forests and Grasslands: A Synthesis of the Scientific Literature, 7-25. USDA Forest Service General Technical Report SRS-39; Dissmeyer, G.E., Ed.; Southern Research Station: Asheville, NC, USA, 2000; Chapter 3, p. 250.

34. Clary, W.P.; Baker, M.B., Jr.; O'Connell, P.F.; Johnsen, T.N., Jr.; Campbell, R.E. Effects of pinyon-juniper removal on natural resource products and uses in Arizona. In USDA Forest Service Research Paper RM-128; Rocky Mountain Forest and Range Experiment Station: Fort Collins, CO, USA, 1974; p. 28.

35. Neary, D.G.; Lassiter, C.J.; Swindel, B.F. Hydrologic responses to silvicultural operations in southern coastal plain flatwoods. In Impacts of Intensive Forest Management Practices; Coleman, S.S., Mace, A.C., Jr., Swindel, B.F., Eds.; School of Forest Resources and Conservation, University of Florida: Gainesville, FL, USA, 1982; p. 110.

36. Pearce, A.J.; Rowe, L.K.; O'Loughlin, C.L. Effects of clearfelling and slash burning on water yield and storm hydrographs in evergreen mixed forests, western New Zealand. In Proceedings of the Influence of Man on the Hydrological Regime with Special Reference to Representative and Experimental Basins, Helsinki, Finland, June 1980; pp. 119-127.

37. Swanson, R.H.; Hillman, G.R. Predicted Increased Water Yield after Clear-Cutting Verified in West Central Alberta. In Information Report NOR-X-198; Canadian Department of Fisheries and Environment, Canadian Forestry Service, Northern Forestry Centre: Edmonton, AB, Canada, 1977.

38. Reinhart, K.G.; Eschner, A.R.; Trimble, G.R., Jr. Effect on streamflow of four forest practices in the mountains of West Virginia. In USDA Forest Service Research Paper NE-1; Northeastern Forest Experiment Station: Broomall, PA, USA, 1974; p. 59.

39. Burch, G.J.; Bath, R.K.; Moore, I.D.; O’Loughlin, E.M. Comparative hydrological behavior of forested and cleared catchments in southeastern Australia. J. Hydrol. 1987, 90, 12-42. [CrossRef]

40. Brown, H.E.; Baker, M.B., Jr.; Rogers, J.J.; Clary, W.C.; Kovner, J.L.; Larson, F.R.; Avery, C.C.; Campbell, R.E. Opportunities for increasing water yields and other multiple use values on ponderosa pine forest lands. In USDA Forest Service Research Paper RM-129; Rocky Mountain Forest and Range Experiment Station: Fort Collins, CO, USA, 1974; p. 36.

41. Lewis, D.C. Annual hydrologic response to watershed conversion from oak woodland to annual grassland. Water Resour. Res. 1968, 4, 59-72. [CrossRef]

42. Rosen, K. Effect of clear-felling on runoff in two small watersheds in central Sweden. Forest Ecol. Manag. 1984, 9, 267-281. [CrossRef]

43. Leaf, C.F. Watershed management in the central and southern Rocky Mountains: A summary of the status of our knowledge by vegetation type. In USDA Forest Service Research Paper RM-142; Rocky Mountain Forest and Range Experiment Station: Fort Collins, CO, USA, 1975; p. 28. 
44. Verry, E.S. Effect of aspen clearcutting on water yield and quality in northern Minnesota. In Watersheds in Transition; Proceedings of a Symposium, Colorado State University, Fort Collins, CO, USA, 19-22 June 1972; Csallany, S.C., McLaughlin, T.G., Striffler, W.D., Eds.; American Water Resources Association: Middleburg, VA, USA, 1972; pp. 276-284.

45. Swanson, R.H.; Golding, D.L.; Rothwell, R.L.; Bernier, P.Y. Hydrologic Effects of Clear-Cutting at Marmot Creek and Streeter Watersheds, Alberta. In Information Report NOR-X-278; Northern Forestry Centre, Canadian Forestry Service: Edmonton, AB, Canada, 1986; p. 27.

46. Nakano, H. Effect on Streamflow of Forest Cutting and Change in Regrowth on Cutover Area; Bulletin of the Japanese Government Forest Experiment Station: Tokyo, Japan, 1971; pp. 1-125.

47. Keppler, E.T.; Ziemer, R.R. Logging effects on streamflow: Water yield and summer low flows at Caspar Creek in northwestern California. Water Resour. Res. 1990, 26, 1669-1679. [CrossRef]

48. Hewlett, J.D.; Doss, R. Forests, floods, and erosion: A watershed experiment in the Southeastern Piedmont. Forest Sci. 1984, 30, 424-434.

49. Hornbeck, J.W.; Martin, C.W.; Pierce, R.S.; Bormann, F.H.; Likens, G.E.; Eaton, J.S. The northern hardwood forest ecosystem: 10 years of recovery from clearcuttting. In USDA Forest Service Research Paper NE-596; Northeastern Forest Experiment Station: Broomall, PA, USA, 1987; p. 30.

50. Miller, E.L.; Beasley, R.S.; Lawson, E.R. Forest harvest and site preparation effects on stormflow and peakflow of ephemeral streams in the Ouachita Mountains. J. Environ. Qual. 1988, 17, 212-218. [CrossRef]

51. Bren, L.J.; Papworth, M. Water yield effects of conversion of slopes of a eucalypt forest catchment to radiata pine plantation. Water Resour. Res. 1991, 27, 2421-2428. [CrossRef]

52. Swift, L.W., Jr.; Swank, W.T. Long-term responses of streamflow following clearcutting and regrowth. In International Association of Hydrological Sciences Publication No. 130 1980, Proceedings on the Influence of Man on the Hydrological Regime with Special Reference to Representative and Experimental Basins, Helsinki, Finland, June 1980; pp. 245-256.

53. Pererira, H.C. Research into the effects of land use on streamflow. Trans. Rhod. Sci. Assoc. Proc. 1964, 1, 119-124.

54. Rothacher, J. Increases in water yield following clear-cut logging in the Pacific Northwest. Water Resour. Res. 1970, 6, 653-658. [CrossRef]

55. Harr, R.D. Forest practices and streamflow in western Oregon. In USDA Forest Service General Technical Report PNW-49; Pacific Northwest Forest and Range Experiment Station: Portland, OR, USA, 1976; p. 18.

56. Harris, D.D. Hydrologic changes after clearcut logging in a small Oregon coastal watershed. J. Res. U.S. Geol. Survey 1973, 1, 487-491.

57. Neary, D.G. Experimental forest catchment studies contributions to the understanding of the effects of disturbances on water quality: Past, present, and future. In International Association of Hydrological Sciences Book, Proceedings of the Workshop "Revisiting Experimental Catchment Studies in Forest Hydrology", 2011 International Union of Geodesy and Geophysics XXV General Assembly, Melbourne, Australia, 6-8 July 2011; Webb, A.A., Bonell, M., Bren, L., Lane, P.N.J., McGuire, D., Neary, D.G., Nettles, J., Scott, D.F., Stednick, J.D., Wang, Y., Eds.; pp. 169-184.

58. Neary, D.G.; Koestner, K.A. Forest bioenergy feedstock harvesting effects on water supply. Wiley 5-Interdisciplinary Reviews in Energy and Environment. WIRES Energy Environ. 2012, 1, 270-284. [CrossRef]

59. Pierce, R.S.; Hornbeck, J.W.; Likens, G.E.; Bormann, F.H. Effect of elimination of vegetation on stream water quality and quantity. Int. Assoc. Hydrol. Sci. 1970, 96, 311-328.

60. Swindel, B.F.; Lassiter, C.J.; Riekerk, H. Effects of clearcutting and site preparation on water yields from slash pine forests. Forest Ecol. Manag. 1982, 4, 101-113. [CrossRef]

61. O'Loughlin, C.L.; Rowe, L.K.; Pearce, A.J. Sediment yield and water quality responses to clearfelling of evergreen mixed forests in western New Zealand. In PIAHS-AISH Publication No. 130, Proceedings of the Helsinki Symposium on the Influence of Man on the Hydrological Regime with Special Reference to Representative and Experimental Basins, Helsinki, Finland, 23-26 June 1980; pp. 285-292.

62. Hopmans, P.; Bren, L.J. Long-term changes in water quality and solute exports in headwater streams of intensely managed radiate pine and natural eucalypt forest catchments in south-eastern Australia. Forest Ecol. Manag. 2007, 253, 244-261. [CrossRef]

63. Bormann, F.H.; Likens, G.E. Nutrient cycling. Science 1967, 155, 424-429. [CrossRef] [PubMed] 
64. Webb, A.A.; Bonell, M.; Bren, L.; Lane, P.N.J.; McGuire, D.; Neary, D.G.; Nettles, J.; Scott, D.F.; Stednick, J.D.; Wang, Y. International Association of Hydrological Sciences Book, Proceedings of the Workshop "Revisiting Experimental Catchment Studies in Forest Hydrology", 2011 International Union of Geodesy and Geophysics XXV General Assembly, Melbourne, Australia, 6-8 July 2011; p. 234.

65. Singh, T.; Kalra, Y.P. Changes in Chemical Composition of Natural Waters Resulting from Progressive Clearcutting of Forest Catchments in West Central Alberta, Canada; International Association of Scientific Hydrology Symposium Proceedings: Tokyo, Japan, 1975; pp. 435-449.

66. Hetherington, E.D. Dennis Creek: A look at water quality following logging in the Okanagan Basin; Environment Canada, Canadian Forestry Service: Ottawa, Canada, 1976; pp. 1-28.

67. Feller, M.C.; Kimmins, J.P. Effects of clearcutting and slash burning on streamwater chemistry and watershed nutrient budgets in southwestern British Columbia. Water Resour. Res. 1984, 20, 29-40. [CrossRef]

68. Krause, H.H. Nitrate formation and movement before and after clear-cutting of a monitored watershed in central New Brunswick, Canada. Can. J. Forest Res. 1982, 12, 922-930. [CrossRef]

69. Carignan, R.; D'Arcy, P.; Lemontagne, S. Comparative impacts of fire and forest harvesting on water quality in Boreal Shield lakes. Can. J. Fish. Aquat. Sci. 2000, 57 (Suppl. S2), S105-S117. [CrossRef]

70. Vaidya, O.C.; Smith, T.P.; Fernand, H.; McInnis, N.R. Best Management Practices: Evaluation of alternate streamside management zones on stream water quality in Pockwock Lake and Five Mile Lake Watersheds in Central Nova Scotia, Canada. Environ. Monit. Assess. 2008, 137, 1-14. [CrossRef] [PubMed]

71. Bateridge, T. Effects of clearcutting on water discharge and nutrient loss. Bitterroot National Forest, Montana. Master's Thesis, Office of Water Resources Research, University of Montana, Missoula, MT, USA, 1974.

72. Stottlemyer, R. Nitrogen mineralization and streamwater chemistry, Rock Creek Watershed, Denali National Park, Alaska, USA. Arch. Alp. Res. 1992, 24, 291-303. [CrossRef]

73. Snyder, G.G.; Haupt, H.F.; Belt, G.H., Jr. Clearcutting and burning slash alter quality of stream water in Northern Idaho. In USDA Forest Service Research Paper INT-1698; Intermountain Forest and Range Experiment Station: Ogden, UT, USA, 1975; p. 34.

74. Fredriksen, R.L.; Moore, D.G.; Norris, L.A. Impact of timber harvest, fertilization, and herbicide treatment on stream water quality in the Douglas-fir regions. In Forest Soils and Forest Land Management, Proceedings of the Fourth North American Forest Soils Conference, Laval University, Quebec City, QC, Canada, August 1973; Bernier, B., Winget, C.H., Eds.; 1975; pp. 283-313.

75. Van Lear, D.H.; Douglass, J.E.; Fox, S.K.; Augsberger, M.K. Sediments and nutrient export in runoff from burned and harvested pine watersheds in the South Carolina Piedmont. J. Environ. Qual. 1985, 14, 169-174. [CrossRef]

76. Swank, W.T. Stream chemistry responses to disturbance. In Forest Hydrology and Ecology at Coweeta; Swank, W.T., Crossley, D.A., Eds.; Springer-Verlag: New York, NY, USA, 1988; Chapter 25; pp. 339-357.

77. Aubertin, G.M.; Patric, J.H. Water quality water after clearcutting a small watershed in West Virginia. J. Environ. Qual. 1974, 3, 243-249. [CrossRef]

78. Oyarzun, C.; Aracena, C.; Rutherford, P.; Godoy, R.; Deschrijver, A. Effects of land use conversion from native forests to exotic plantations on nitrogen and phosphorus retention in catchments of southern Chile. Water Air Soil Pollut. 2007, 179, 341-350. [CrossRef]

79. Ahtiainen, M.; Huttunen, P. Long-term effects of forestry managements on water quality and loading in brooks. Boreal Environ. Res. 1999, 4, 101-114.

80. Bäumler, R.; Zech, W. Effects of forest thinning on the streamwater chemistry of two forest watersheds in the Bavarian Alps. Forest Ecol. Manag. 1999, 116, 119-128. [CrossRef]

81. Ohrui, K.; Mitchell, M.J. Stream water chemistry in Japanese forested watersheds and its variability on a small regional scale. Water Resour. Res. 1998, 34, 1553-1561. [CrossRef]

82. Graynoth, E. Effects of logging on stream environments and faunas in Nelson. N. Z. J. Mar. Freshw. 1979, 13, 79-109. [CrossRef]

83. O'Loughlin, C.L. The forest and water quality relationship. N. Z. For. 1994, 39, 26-30.

84. Scott, D.F.; Lesch, W. Streamflow responses to afforestation with Eucalyptus grandis and Pinus. patula and to felling in the Mokobulaan experimental catchments. J. Hydrol. 1997, 199, 360-377. [CrossRef]

85. Rosen, K. Effect of clear-felling on streamwater quality in forest catchments in central Sweden. Forest Ecol. Manag. 1996, 83, 237-244. [CrossRef] 
86. Neal, C.; Fisher, R.; Smith, C.J.; Hill, S.; Neal, M.; Conway, T.; Ryland, G.P.; Jeffrey, H.A. The effects of tree harvesting on stream-water quality at an acidic and acid-sensitive spruce forested area: Plynlimon, mid-Wales. J. Hydrol. 1992, 135, 305-319. [CrossRef]

87. Neary, D.G. Impact of timber harvesting on nutrient losses in streamflow. N. Z. J. For. 1977, 22, 53-63.

88. Webb, A.A.; Bonell, M.; Bren, L.; Lane, P.N.J.; McGuire, D.; Neary, D.G.; Nettles, J.; Scott, D.F.; Stednick, J.D.; Wang, Y. Revisiting Experimental Catchment Studies in Forest Hydrology; IAHS Press: Wallingford, UK, 2012; p. 235.

89. Swank, W.T.; Crossley, D.A. Forest Hydrology and Ecology at Coweeta; Springer-Verlag: New York, NY, USA, 1988; p. 469.

(C) 2016 by the author; licensee MDPI, Basel, Switzerland. This article is an open access article distributed under the terms and conditions of the Creative Commons Attribution (CC-BY) license (http://creativecommons.org/licenses/by/4.0/). 